\title{
Chapter 11 \\ Excretion of Cesium Through Potassium Transport Pathway in the Gills of a Marine Teleost
}

\author{
Toyoji Kaneko, Fumiya Furukawa, and Soichi Watanabe
}

\begin{abstract}
We used a newly developed technique that insolubilizes and visualizes $\mathrm{K}^{+}$ excreted from the gills to demonstrate that gill mitochondria-rich (MR) cells are responsible for $\mathrm{K}^{+}$excretion in seawater-acclimated Mozambique tilapia. To achieve a better understanding of the molecular mechanism of $\mathrm{K}^{+}$excretion from the gills, we identified the cDNA sequences of some candidate molecules that may be involved in $\mathrm{K}^{+}$transport. Of these candidate molecules, only a renal outer medullary $\mathrm{K}^{+}$channel (ROMK) exhibited markedly upregulated mRNA levels in response to a high external $\mathrm{K}^{+}$concentration. We found that ROMK expressed in the apical opening of MR cells was the main molecular pathway responsible for $\mathrm{K}^{+}$excretion. Using the insolubilization technique, we further demonstrated the excretion of $\mathrm{Cs}^{+}$and $\mathrm{Rb}^{+}$, which are known to be biochemical analogs of $\mathrm{K}^{+}$, through the $\mathrm{K}^{+}$transport pathway in the gills of seawater tilapia. The activation of ROMK in the gill MR cells induced by $\mathrm{K}^{+}$supplementation could eliminate unnecessary biochemical analogs of $\mathrm{K}^{+}$more rapidly, possibly serving as an effective countermeasure against radiocesium in aquaculture.
\end{abstract}

Keywords Cesium $\bullet$ Mitochondria-rich cell - Mozambique tilapia Potassium

- Renal outer medullary $\mathrm{K}^{+}$channel $\bullet$ Rubidium

\section{Abbreviations}

Cs Cesium

$\mathrm{Rb}$ Rubidium

T. Kaneko $(\triangle) \bullet$ F. Furukawa $\bullet$ S. Watanabe Graduate School of Agricultural and Life Sciences, The University of Tokyo,

1-1-1 Yayoi, Bunkyo, Tokyo 113-8657, Japan

e-mail: kaneko31@marine.fs.a.u-tokyo.ac.jp 


\subsection{Introduction}

The recent nuclear accident at the Fukushima Daiichi nuclear power plant in Japan released massive amounts of radioactive materials into the environment including radiocesium $\left({ }^{134} \mathrm{Cs}\right.$ and $\left.{ }^{137} \mathrm{Cs}\right)$. Cesium belongs to the alkali metal group and shares chemical properties with $\mathrm{K}$ and $\mathrm{Rb}$; therefore, it is regarded as a biochemical analog of K (Relman 1956). Radiocesium is considered to behave like K in living organisms after being absorbed into the body because of its similar biochemical properties. Similar to terrestrial animals, aquatic animals are at a high risk of radioactive contamination because radioactive pollutants enter rivers and the ocean. In particular, marine teleosts are vulnerable to the absorption of higher levels of minerals dissolved in seawater because they drink a large amount of ambient seawater to compensate for their osmotic water loss (Evans et al. 2005; Marshall and Grosell 2006). Assuming that Cs behaves exactly like K, it is critical to clarify the excretory pathway of $\mathrm{K}$ in marine teleosts. Although the precise molecular mechanisms for the regulation of plasma $\mathrm{Na}^{+}$and $\mathrm{Cl}^{-}$, which are the major ions in the plasma, have been elucidated in several stenohaline and euryhaline teleosts (Marshall and Grosell 2006), less information is available on the regulatory mechanisms of $\mathrm{K}^{+}$.

Our recent findings indicate that excess $\mathrm{K}^{+}$is excreted from the gills in marine teleosts (Furukawa et al. 2012a), as is the case with $\mathrm{Na}^{+}$and $\mathrm{Cl}^{-}$secretion. The gills are also responsible for eliminating unnecessary $\mathrm{Cs}^{+}$and $\mathrm{Rb}^{+}$, which are biochemical analogs of $\mathrm{K}^{+}$, from the body fluid, presumably through the $\mathrm{K}^{+}$excretion pathway in the gills (Furukawa et al. 2012b). In this chapter, we review recent advances in the understanding of $\mathrm{K}^{+}$regulation in teleost fish and provide basic information related to possible countermeasures for radiocesium in aquaculture.

\subsection{Osmoregulation in Teleost Fishes}

\subsubsection{Body Fluid Osmolality}

Body fluid osmolality is an essential prerequisite for vertebrate species, including teleosts, in order to maintain various chemical and physical parameters of the body fluids within certain physiological ranges, which ensures the normal activities of the cells that constitute the body. One of the most important factors that define the characteristics of body fluids is the osmotic pressure, or osmolality, which is determined by the total concentration of solutes (osmolytes) in the body fluid, mostly inorganic electrolytes. Because $\mathrm{Na}^{+}$and $\mathrm{Cl}^{-}$are the major electrolytes in the blood plasma, the regulation of both $\mathrm{Na}^{+}$and $\mathrm{Cl}^{-}$is critical for osmoregulation. Another important factor is regulation of the water balance because water acts as a solvent for osmolytes. Thus, vertebrates regulate their body fluid osmolality by controlling their ion concentration and water content. 


\subsubsection{Passive Ion and Water Movements in Teleosts}

Teleost species that inhabit aquatic environments experience different osmotic challenges compared with terrestrial vertebrates. Aquatic animals such as teleosts possess gills, which are permeable to ions and water to some extent, as their respiratory organs. Ion and water movements depend on concentration and osmotic gradients, respectively, between the body fluid and the external aquatic environment. This is not the case with terrestrial vertebrates, where gas exchange occurs through the air in the lungs. Teleost fish have developed excellent osmoregulatory mechanisms that maintain their ion and water balance in a wide environmental salinity range.

\subsubsection{Freshwater and Seawater Adaptation}

As with most other vertebrate species, teleosts maintain the osmolality of their body fluids at a constant level of approximately 1/3rd of seawater osmolality. Osmoregulation in adult teleosts is mainly the result of integrated ion and water transport activities in the gills, kidneys, and intestine (Evans et al. 2005; Marshall and Grosell 2006). Freshwater teleosts experience water load and salt loss through their permeable body surfaces, most of which occur through their gill epithelia. To overcome these problems, they discharge excess water by producing dilute urine in their kidneys and they absorb ions through their gill epithelia. In contrast, marine teleosts must cope with water loss and their salt load. The water loss is compensated by drinking seawater and absorbing water in the intestine, whereas the excess ions are actively excreted from the gills and kidneys. Therefore, in adult fish, the gills, kidneys, and intestine are important osmoregulatory organs that create ionic and osmotic gradients between the body fluids and the external environment. Of the ion-transporting epithelial cells found in these osmoregulatory organs, the mitochondria-rich (MR) cells, or chloride cells, found in the gill epithelia are the main sites of ion secretion and absorption, which are important for seawater and freshwater adaptation, respectively (Kaneko et al. 2008). MR cells are also involved in acid-base regulation and $\mathrm{Ca}^{2+}$ uptake and thus play crucial roles in the adaptation to various osmotic and ionic aquatic environments.

\subsubsection{MR Cells}

MR cells are characterized by the presence of numerous mitochondria in their cytoplasm, which allows detection of MR cells using mitochondria-specific fluorescent probes, such as DASPEI, Rhodamine 123, and MitoTrackers, with a fluorescence or confocal laser scanning microscope (Kaneko et al. 2008). The cells are also characterized by an extensive tubular system in the cytoplasm. This tubular system is continuous with the basolateral membrane, which presents a large surface area for the localization of ion 


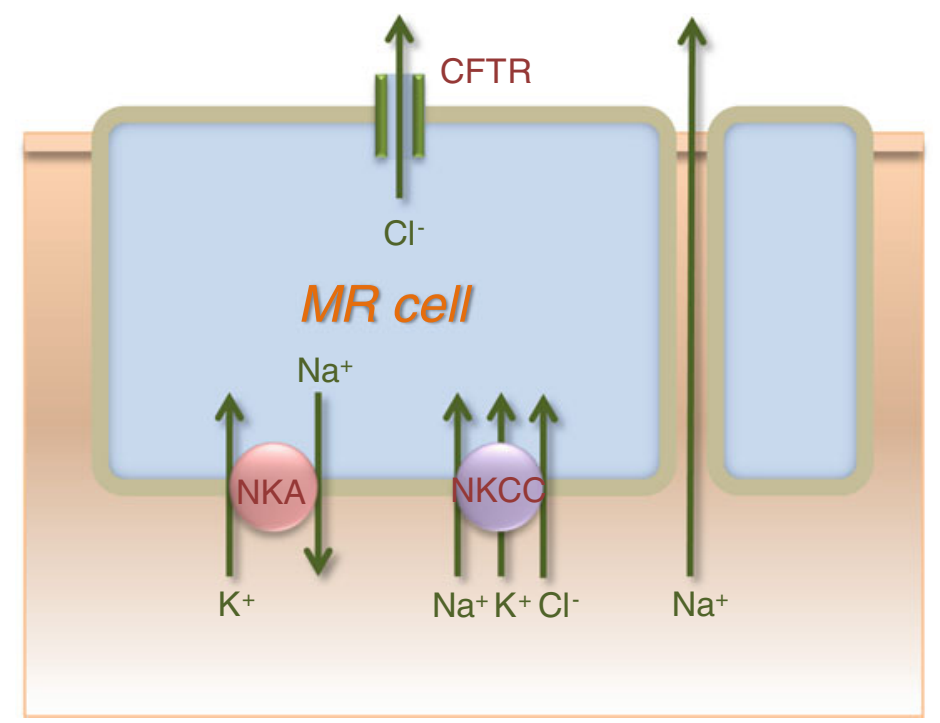

Fig. 11.1 Molecular mechanisms of $\mathrm{Na}^{+}$and $\mathrm{Cl}^{-}$secretion from mitochondria-rich (MR) cells in seawater fish, involving the cooperative actions of three major ion transporters: $\mathrm{Na}^{+} / \mathrm{K}^{+}$-ATPase (NKA), $\mathrm{Na}^{+} / \mathrm{K}^{+} / 2 \mathrm{Cl}^{-}$cotransporter (NKCC), and cystic fibrosis transmembrane conductance regulator (CFTR) $\mathrm{Cl}^{-}$channel

transporting proteins. Of these, $\mathrm{Na}^{+} / \mathrm{K}^{+}$-ATPase is a key enzyme with ion transporting functions in MR cells, which creates ionic and electronic gradients and provides the major driving force for ion secretion and absorption in MR cells (McCormick 1995).

\subsubsection{Molecular Mechanisms Underlying the Ion Transporting Functions of MR Cells}

The current accepted model of $\mathrm{Na}^{+}$and $\mathrm{Cl}^{-}$secretion from MR cells in seawater fish (Fig. 11.1) involves the cooperative action of three major ion transporters: $\mathrm{Na}^{+} / \mathrm{K}^{+}-$ ATPase, $\mathrm{Na}^{+} / \mathrm{K}^{+} / 2 \mathrm{Cl}^{-}$cotransporter $(\mathrm{NKCC}$ ), and cystic fibrosis transmembrane conductance regulator (CFTR) $\mathrm{Cl}^{-}$channel (Hirose et al. 2003; Evans et al. 2005). The basolaterally located $\mathrm{Na}^{+} / \mathrm{K}^{+}$-ATPase causes low intracellular $\mathrm{Na}^{+}$concentration and a high negative charge within the cell. This $\mathrm{Na}^{+}$gradient is used to transport $\mathrm{Na}^{+}, \mathrm{K}^{+}$, and $2 \mathrm{Cl}^{-}$into the cell through the basolateral $\mathrm{NKCC}$. $\mathrm{Next}, \mathrm{Cl}^{-}$exits the cells down on an electrical gradient through an apical $\mathrm{Cl}^{-}$channel, whereas $\mathrm{Na}^{+}$is transported back outside the cells by $\mathrm{Na}^{+} / \mathrm{K}^{+}$-ATPase before being secreted through the paracellular pathway formed between MR and adjacent accessory cells.

However, the mechanisms underlying ion uptake in MR cells of freshwater fish are still unclear and controversial, although several different models have been proposed for ion absorption by MR cells (Hirose et al. 2003). The difficulty lies in the fact that 
different species may possess different mechanisms and that each species may have more than one type of ion-absorbing MR cell. For example in Mozambique tilapia (Oreochromis mossambicus), two distinct types of MR cells have been observed in freshwater-acclimated fish, i.e., MR cells with apically expressed $\mathrm{Na}^{+} / \mathrm{H}^{+}$exchanger 3 and those with apically expressed $\mathrm{Na}^{+} / \mathrm{Cl}^{-}$cotransporter (Inokuchi et al. 2008).

\subsubsection{Possible $\mathrm{K}^{+}$Secretion from the Gills}

While the molecular mechanisms of $\mathrm{Na}^{+}, \mathrm{Cl}^{-}$, and acid-base regulation and those of nitrogen metabolite excretion in fish MR cells have become increasingly clear (Hwang et al. 2011), the regulatory mechanisms of $\mathrm{K}^{+}$in fish is yet to be identified. In general, $\mathrm{K}^{+}$is a major monovalent cation in vertebrate animals (Their 1986). Due to the action of $\mathrm{Na}^{+} / \mathrm{K}^{+}$-ATPase on the cell membrane, a large proportion of $\mathrm{K}^{+}$is confined within cells, whereas the plasma $\mathrm{K}^{+}$concentration is maintained at a relatively low level. Terrestrial animals regulate their plasma $\mathrm{K}^{+}$levels within physiological ranges by modulating renal $\mathrm{K}^{+}$excretion in the urine. In the mammalian kidney, the renal outer medullary potassium channel (ROMK or Kir 1.1), located in the apical membrane of tubular epithelial cells from the thick ascending limb through the outer medullary collecting duct, is the main route for $\mathrm{K}^{+}$secretion to the lumen (Hebert et al. 2005). Other proteins involved in $\mathrm{K}^{+}$handling are also expressed in the mammalian kidney, such as the $\mathrm{K}$ large conductance $\mathrm{Ca}^{2+}$-activated channel, subfamily $\mathrm{M}$ (Maxi-K or BK), and $\mathrm{K}^{+}-\mathrm{Cl}^{-}$cotransporters (KCC1, KCC3, and $\mathrm{KCC} 4$ ) (Wang and Giebisch 2009).

Seawater contains more than twice as much $\mathrm{K}^{+}$as the typical plasma in vertebrate animals. However, seawater-inhabiting fish produce a small amount of $\mathrm{K}^{+}-$ poor isosmotic urine, which is insufficient to maintain an appropriate internal $\mathrm{K}^{+}$ level. Thus, seawater fish are considered to have an extra-renal mechanism that eliminates any excess $\mathrm{K}^{+}$from their body fluids. In this context, we recently demonstrated the excretion of $\mathrm{K}^{+}$from the gills and elucidated its molecular mechanism in seawater-acclimated Mozambique tilapia (Furukawa et al. 2012a).

\section{3 $\mathrm{K}^{+}$Secretion from MR Cells}

\subsubsection{Visualization of $\mathrm{K}^{+}$Secretion from Gill MR Cells}

Using a newly developed technique that insolubilized and visualized $\mathrm{K}^{+}$excreted from the gills, we demonstrated that gill MR cells were responsible for $\mathrm{K}^{+}$excretion in seawater-acclimated Mozambique tilapia (Furukawa et al. 2012a). Mozambique tilapia is one of the most suitable fish species for studies on osmoregulation because this euryhaline tilapia is adaptable not only to a wide range of salinity from freshwater to seawater but also to extremely low-ion water and even concentrated seawater. 
To determine the site of $\mathrm{K}^{+}$excretion, $\mathrm{K}^{+}$was reacted with sodium tetraphenylborate (TPB) to form insoluble precipitates of K-TPB. The gills of seawateracclimated tilapia were dissected out and washed using $0.025 \% \mathrm{KMnO}_{4}$ in $\mathrm{PBS}$ for 1 min to remove mucus from the filament surface. After washing with mannitol solution (320 mM mannitol, $1.8 \mathrm{mM} \mathrm{CaCl}_{2}$ ), the gill filaments were placed in a reaction solution containing $30 \mathrm{mM} \mathrm{Na}-\mathrm{TPB}, 265 \mathrm{mM}$ mannitol, $1.8 \mathrm{mM} \mathrm{CaCl}$, and $50 \mathrm{mM}$ HEPES (TPB solution). After $30 \mathrm{~s}$, the TPB solution was removed and the filaments were washed using mannitol solution. To label the MR cells, the gill filaments were immersed for $15 \mathrm{~min}$ in a solution containing $0.05 \mathrm{mM}$ rhodamine 123, $2 \mathrm{mM}$ HEPES, $2.7 \mathrm{mM} \mathrm{KCl}, 0.4 \mathrm{mM} \mathrm{MgCl}_{2}, 158 \mathrm{mM} \mathrm{NaCl}$, and $1.8 \mathrm{mM}$ $\mathrm{CaCl}_{2}$. The samples were then observed using a confocal laser scanning microscope. The TPB-treated gill filaments were also analyzed by energy dispersive $\mathrm{X}$-ray spectrometry (EDS) to confirm the presence of $\mathrm{K}$ in the precipitates observed in the apical openings of MR cells. After fixation in $4 \%$ paraformaldehyde in $0.1 \mathrm{M}$ phosphate buffer ( $\mathrm{pH}$ 7.4) for $24 \mathrm{~h}$, the gill filaments were washed with distilled water and snap-frozen in liquid $\mathrm{N}_{2}$. The frozen filaments were dried in a freezedryer. The dried filaments were mounted on specimen stubs, coated with Au in an ion coater, and analyzed using a scanning electron microscope (SEM) equipped with an EDS system.

When the gills were observed by differential interference contrast (DIC) microscopy, precipitates of possible K-TPB were visible as particles on the gills (Fig. 11.2a). The particles were localized in the apical openings of MR cells, which were confirmed by merging the DIC image with the corresponding fluorescent image of MR cells (Fig. 11.2b). In the SEM observations, the precipitates were visible as amorphous structures attached to the surface of the gill filaments (Fig. 11.2c). The EDS analysis showed that the $\mathrm{K}$ signals were closely associated with the precipitates (Fig. 11.2d). These findings clearly indicated that $\mathrm{K}^{+}$was secreted from gill MR cells in seawater-acclimated tilapia.

\subsubsection{Molecular Mechanism of $\mathrm{K}^{+}$Secretion}

To achieve a better understanding of the molecular mechanism of $\mathrm{K}^{+}$excretion from the gills, we identified the cDNA sequences of the candidate molecules that could be involved in $\mathrm{K}^{+}$handling in the Mozambique tilapia gills, such as the renal outer medullary $\mathrm{K}^{+}$channel $(\mathrm{ROMK}), \mathrm{K}$ large conductance $\mathrm{Ca}^{2+}$-activated channel, subfamily $\mathrm{M}$ (Maxi-K), and $\mathrm{K}^{+}-\mathrm{Cl}^{-}$cotransporters $(\mathrm{KCC} 1, \mathrm{KCC} 2$, and KCC4). The tissue distribution patterns of ROMK, Maxi-K, KCC1, KCC2, and KCC4 mRNA expression were analyzed by RT-PCR in freshwater- and seawateracclimated tilapia. All of them were confirmed to be expressed in the gills, with the exception of KCC2, which was exclusively expressed in the brain.

To further determine the primary $\mathrm{K}^{+}$channel or transporter involved in $\mathrm{K}^{+}$secretion in the branchial MR cells, we compared the expression levels of the candidate 

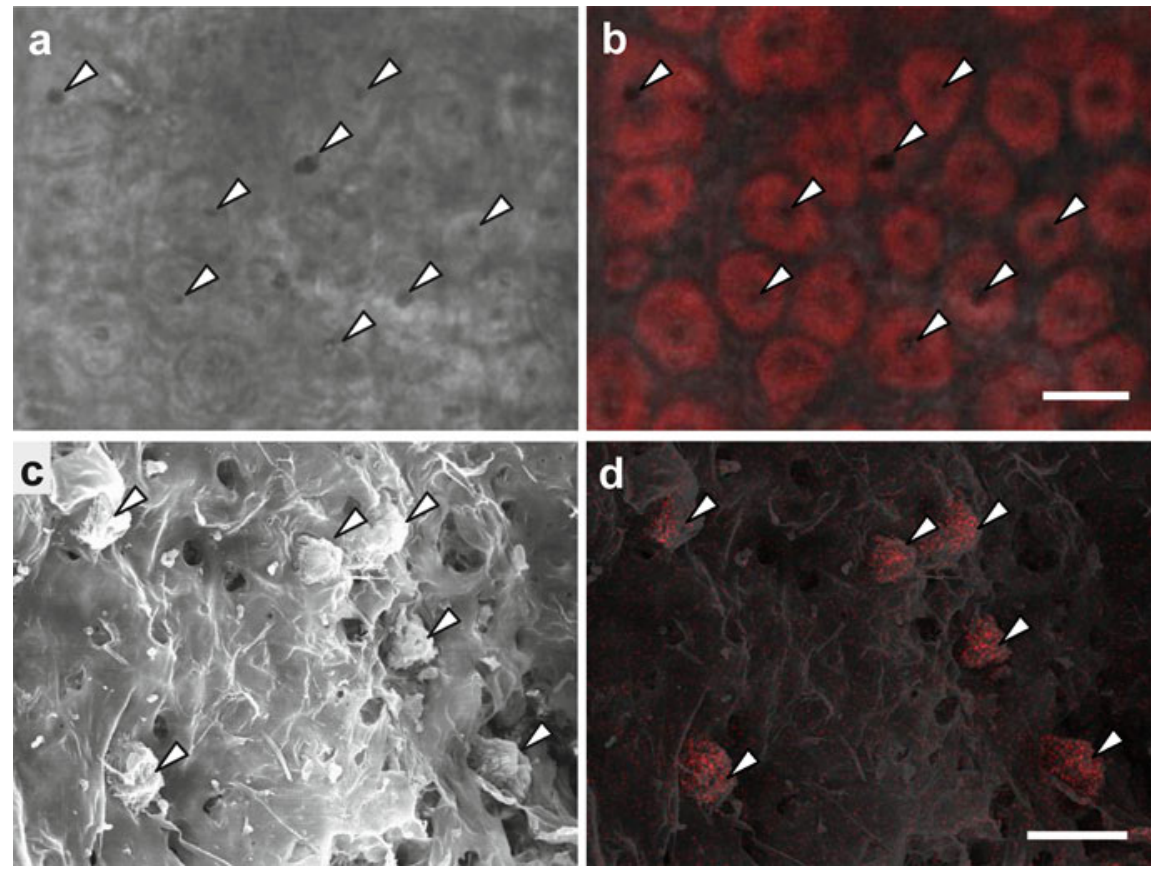

Fig. 11.2 Detection of $\mathrm{K}^{+}$excreted by the gills of seawater-acclimated Mozambique tilapia. A transmitted differential interference contrast (DIC) image of the precipitates (arrowheads) formed on the gill surface (a) and a DIC image merged with a panfocal fluorescent micrograph showing mitochondria-rich cells (red) in the same field (b). A scanning electron micrograph of the precipitate (arrowheads) on the gill surface (c), and the same image merged with a mapping image of potassium obtained using energy dispersive X-ray spectrometry (d). Bars, $20 \mu \mathrm{m}$ (modified from Furukawa et al. 2012a)

molecules in the gills of Mozambique tilapia acclimated to environments with different $\mathrm{K}^{+}$concentrations. The tilapia were acclimated to freshwater $\left(\mathrm{K}^{+}\right.$, $<0.1 \mathrm{mM})$, seawater $(8 \mathrm{mM})$, and artificial seawater containing moderate $(8 \mathrm{mM})$ and high $(17 \mathrm{mM})$ concentrations of $\mathrm{K}^{+}$for 1 week. Of the candidate molecules, ROMK exhibited marked upregulation of mRNA levels in response to a high external $\mathrm{K}^{+}$concentration (Fig. 11.3a), whereas the expression levels of Maxi-K, $\mathrm{KCC} 1$, and $\mathrm{KCC} 4$ did not change significantly in response to the environmental $\mathrm{K}^{+}$. These findings suggest that ROMK is the key molecule involved in $\mathrm{K}^{+}$secretion from MR cells.

In addition to ROMK, NKCC1a tended to be highly expressed in high $\mathrm{K}^{+}$ environments (Fig. 11.3b). NKCC1a was expressed in the basolateral membrane of seawater-type ion-secretory MR cells (Fig. 11.1). Although $\mathrm{K}^{+}$enters MR cells primarily through the basolateral $\mathrm{Na}^{+} / \mathrm{K}^{+}$-ATPase, the upregulation of NKCC1a in tilapia acclimated to high $\mathrm{K}^{+}$conditions may contribute to additional $\mathrm{K}^{+}$entry into MR cells. 

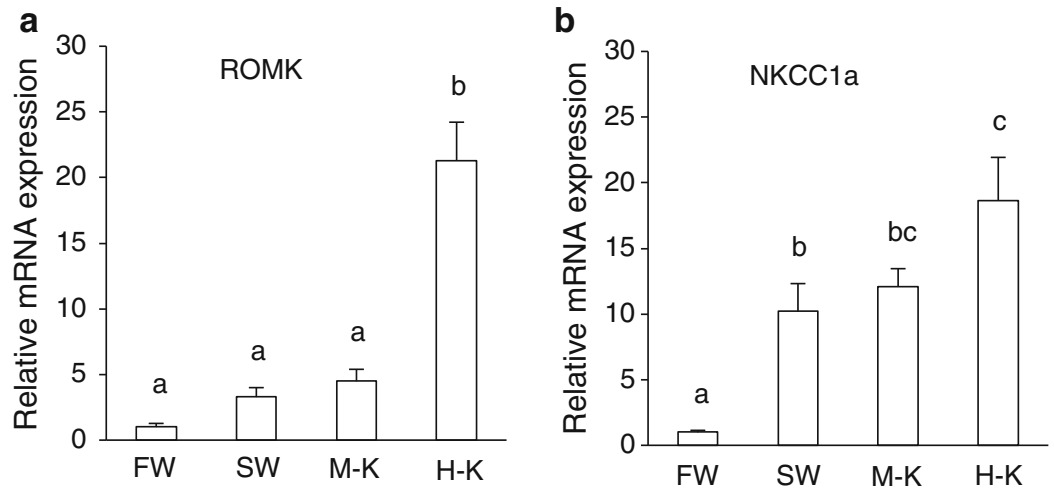

Fig. 11.3 Expression levels of ROMK (a) and NKCC1a (b) mRNAs in the gills of tilapia acclimated to freshwater $\left(\mathrm{FW},\left[\mathrm{K}^{+}\right]<0.1 \mathrm{mM}\right)$, seawater $(\mathrm{SW}, 8 \mathrm{mM})$, and artificial $\mathrm{SW}$ with moderate $(\mathrm{M}-\mathrm{K}, 8 \mathrm{mM})$ and high $(\mathrm{H}-\mathrm{K}, 17 \mathrm{mM})$ concentrations of $\mathrm{K}^{+}$for 1 week. Data are expressed as mean \pm SE $(n=6)$. Different letters indicate significant differences at $p<0.05$ (modified from Furukawa et al. 2012a)

\subsubsection{Confirmation of $\mathrm{K}^{+}$Secretion Through $\mathrm{ROMK}$}

The $\mathrm{K}^{+}$secretory function of ROMK was further confirmed by exposing the gills to TPB solution containing $\mathrm{Ba}^{2+}$, a non-selective blocker of ROMK and Maxi-K, or iberiotoxin (IBTX), a specific blocker of Maxi-K. In the control, $\mathrm{K}$-TPB precipitates were evident on the surfaces of the gills. Treatment with $5 \mathrm{mM} \mathrm{Ba}^{2+}$ inhibited the formation of K-TPB precipitates, whereas $200 \mathrm{nM}$ IBTX did not. These results support the conclusion that $\mathrm{K}^{+}$excretion occurs mainly through ROMK.

To localize ROMK protein in the gill MR cells, the gill filaments of Mozambique tilapia acclimated to environments containing different $\mathrm{K}^{+}$concentrations were double-stained using an antiserum raised against tilapia ROMK and anti- $\mathrm{Na}^{+} / \mathrm{K}^{+}$ATPase for detecting MR cells. Immunofluorescence microscopy showed that ROMK was localized in the apical openings of $\mathrm{Na}^{+} / \mathrm{K}^{+}$-ATPase-immunoreactive MR cells (Fig. 11.4) and that the ROMK immunoreaction was most intense in fish acclimated to environments with a high $\mathrm{K}^{+}$concentration (Fig. 11.4d). In contrast, the immunoreaction was weak in fish acclimated to freshwater (Fig. 11.4a).

Ordinary cells contain approximately $140 \mathrm{mM} \mathrm{K}^{+}$in their cytoplasm, but MR cells are likely to be richer in $\mathrm{K}^{+}$due to the active basolateral uptake of $\mathrm{K}^{+}$through $\mathrm{Na}^{+} / \mathrm{K}^{+}$-ATPase and NKCC1a. Thus, the concentration gradient across the apical membrane of MR cells favors $\mathrm{K}^{+}$excretion through ROMK to the external environment. The strong ROMK immunoreaction of MR cells in high $\mathrm{K}^{+}$-acclimated fish indicates a higher density of ROMK in the apical openings of MR cells, suggesting the elimination of excess $\mathrm{K}^{+}$at a higher rate. 

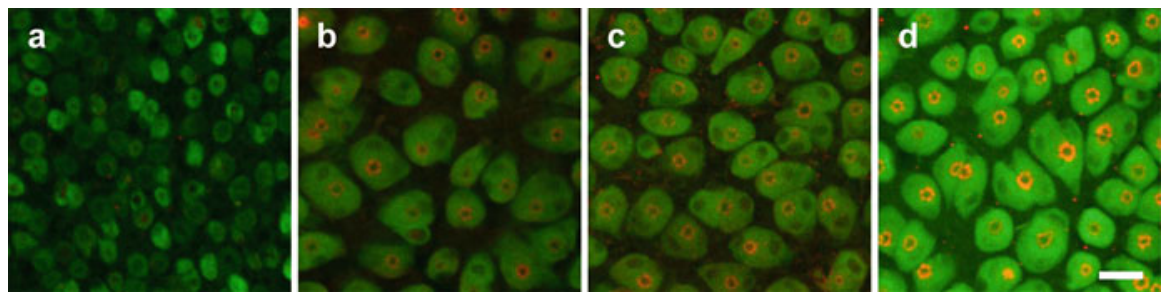

Fig. 11.4 Immunofluorescence micrographs of gills stained with anti-Na+ $\mathrm{N}^{+}-\mathrm{ATPase}$ (NKA, green) and anti-ROMK (red) in tilapia acclimated to freshwater (a), seawater (b), and artificial seawater with moderate (c) and high concentrations (d) of $\mathrm{K}^{+}$. Bar, $20 \mu \mathrm{m}$ (modified from Furukawa et al. 2012a)

\section{4 $\mathrm{Cs}^{+}$and $\mathrm{Rb}^{+}$Secretion from MR Cells}

\subsection{1 $C \mathrm{~s}^{+}$and $\mathrm{Rb}^{+}$as Biochemical Analogs of $\mathrm{K}^{+}$}

Small amounts of $\mathrm{Cs}^{+}$and $\mathrm{Rb}^{+}$, which are generally considered to be biochemical analogs of $\mathrm{K}^{+}$, are detectable in fishes and seawater, although their concentrations are much lower than that of $\mathrm{K}^{+}$. The distributions of $\mathrm{Cs}^{+}$and $\mathrm{Rb}^{+}$have also been studied in fish, where these ions are mainly located in the muscle (Peters et al. 1999). Although the elimination route of $\mathrm{Cs}^{+}$and $\mathrm{Rb}^{+}$is still unclear, the $\mathrm{K}^{+}$excretion pathway in the branchial epithelium is a strong candidate for the elimination of these ions.

In spite of little physiological impact of non-radioactive $\mathrm{Cs}^{+}$in fish, the radiocesium $\left({ }^{137} \mathrm{Cs}\right.$ and $\left.{ }^{134} \mathrm{Cs}\right)$ fallout generated by the recent nuclear disaster at the Fukushima Daiichi nuclear power plant in Japan caused extensive damage to the surrounding environment and living organisms. Marine teleosts were also contaminated by radiocesium. Thus, it is very important to know whether marine teleosts can secrete $\mathrm{Cs}^{+}$through the $\mathrm{K}^{+}$transport pathway in the gill MR cells.

\subsubsection{Detection of $\mathrm{Cs}^{+}$and $\mathrm{Rb}^{+}$Excreted from the Gills}

To detect $\mathrm{Cs}^{+}$and $\mathrm{Rb}^{+}$possibly excreted from the gills, we used the $\mathrm{K}^{+}$insolubilization technique with some modifications because $\mathrm{Na}-\mathrm{TPB}$ reacts not only with $\mathrm{K}^{+}$but also with $\mathrm{Cs}^{+}$and $\mathrm{Rb}^{+}$to form insoluble precipitates. A gill arch in seawateracclimated tilapia was cut at the ventral end and infused intra-arterially for $>1 \mathrm{~min}$ with $1 \mathrm{ml}$ of balanced salts solution (BSS; $140 \mathrm{mM} \mathrm{Na}^{+}, 146 \mathrm{mM} \mathrm{Cl}^{-}, 2.95 \mathrm{mM} \mathrm{K}^{+}$, $1.5 \mathrm{mM} \mathrm{Ca}^{2+}, 1.29 \mathrm{mM} \mathrm{Mg}^{2+}, 5 \mathrm{mM}$ HEPES, $\mathrm{pH}$ 7.5), where $\mathrm{K}^{+}$was replaced with the same amount of $\mathrm{Cs}^{+}(\mathrm{Cs}-\mathrm{BSS})$ or $\mathrm{Rb}^{+}(\mathrm{Rb}-\mathrm{BSS})$. After replacing the blood with Cs-BSS or Rb-BSS, the gills were dissected out and incubated in BSS for 10 min to allow the infused $\mathrm{Cs}^{+}$or $\mathrm{Rb}^{+}$to spread. The gills were then treated with TPB solution, in the same manner as described previously, and subjected to SEM observation 

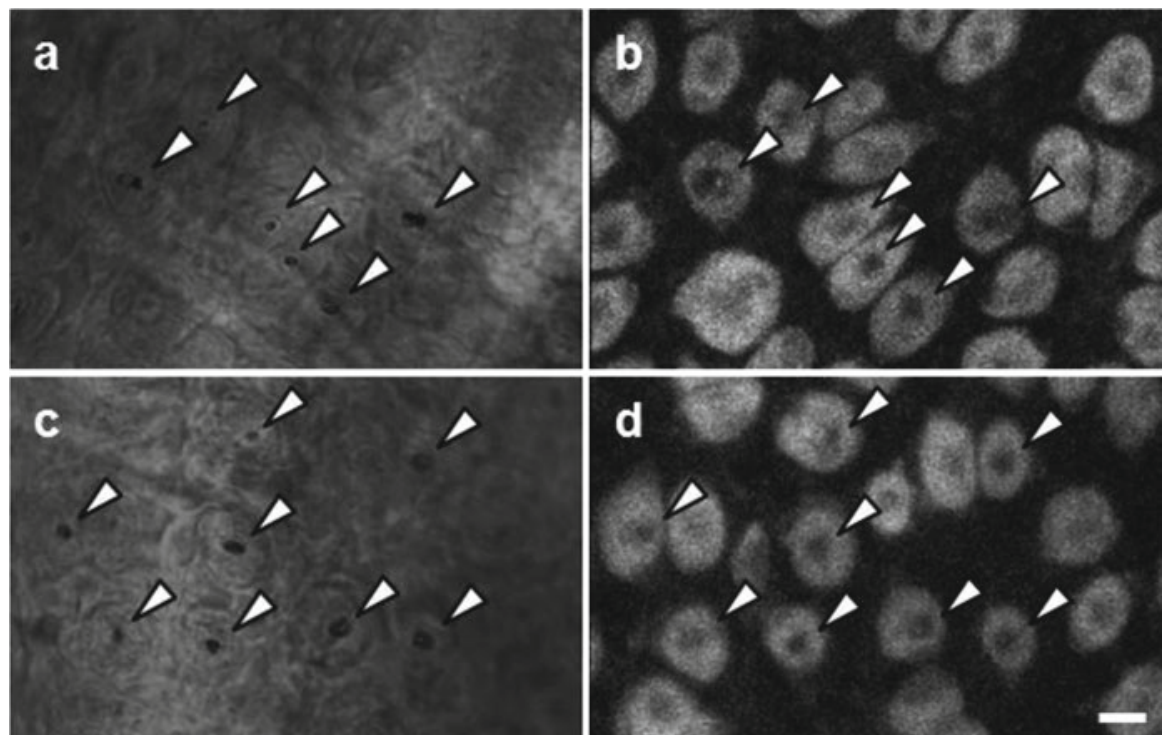

Fig. 11.5 Transmitted differential interference contrast images of the precipitates (arrowheads) on gills infused with $\mathrm{Rb}^{+}(\mathbf{a})$ and $\mathrm{Cs}^{+}(\mathbf{c})$, and those merged with panfocal fluorescent micrographs showing mitochondria-rich (MR) cells $(\mathbf{b}, \mathbf{d})$. The precipitates are shown on MR cells stained with rhodamine 123 (b, d) on the gill epithelia. Bar, $10 \mu \mathrm{m}$ (from Furukawa et al. 2012b)

and EDS analysis. To simultaneously detect ion excretion and MR cells, some gills were infused with Cs-BSS or Rb-BSS containing $50 \mu \mathrm{M}$ rhodamine 123 and examined using a confocal laser scanning microscope.

After treatment with TPB solution, the precipitates were observed as black particles on the openings of MR cells (Fig. 11.5), in a similar manner to the previous observations (Fig. 11.2a, b). The gill surface areas with and without precipitates were subjected to EDS analysis to obtain their X-ray energy spectra (Fig. 11.6). $\mathrm{X}$-ray energy peaks characteristic of Cs were detected in the areas of Cs-BSSinfused gills with precipitates (Fig. 11.6e, f). Similarly, an X-ray energy peak that was characteristic of $\mathrm{Rb}$ was detected in the areas of Rb-BSS-infused gills with precipitates (Fig. 11.6a, b). These precipitates also showed a sharp X-ray energy peak characteristic of $\mathrm{K}$. In contrast, there were no clear X-ray energy peaks for $\mathrm{K}$, $\mathrm{Cs}$, or $\mathrm{Rb}$ in the areas devoid of the precipitates, irrespective of whether the samples were infused with Cs-BSS or Rb-BSS (Fig. 11.6c, d, g, h).

The distribution patterns of $\mathrm{K}, \mathrm{Cs}$, and $\mathrm{Rb}$ on the lines across the precipitates were also examined by EDS line-scanning analysis (Fig. 11.7). In the $\mathrm{Rb}$-BSS-infused gills, there was a clear correspondence between the distribution patterns of $\mathrm{K}$ and $\mathrm{Rb}$, and both elements were specifically detected in the precipitate (Fig. 11.7a, c, e). Similarly, the characteristic X-ray spectra of K and Cs were specifically detected in the precipitate in Cs-BSS-infused gills (Fig. 11.7b, d, f). Overall, these results suggest that $\mathrm{Rb}^{+}$and $\mathrm{Cs}^{+}$were excreted through the $\mathrm{K}^{+}$transport pathway in the gill MR cells. 

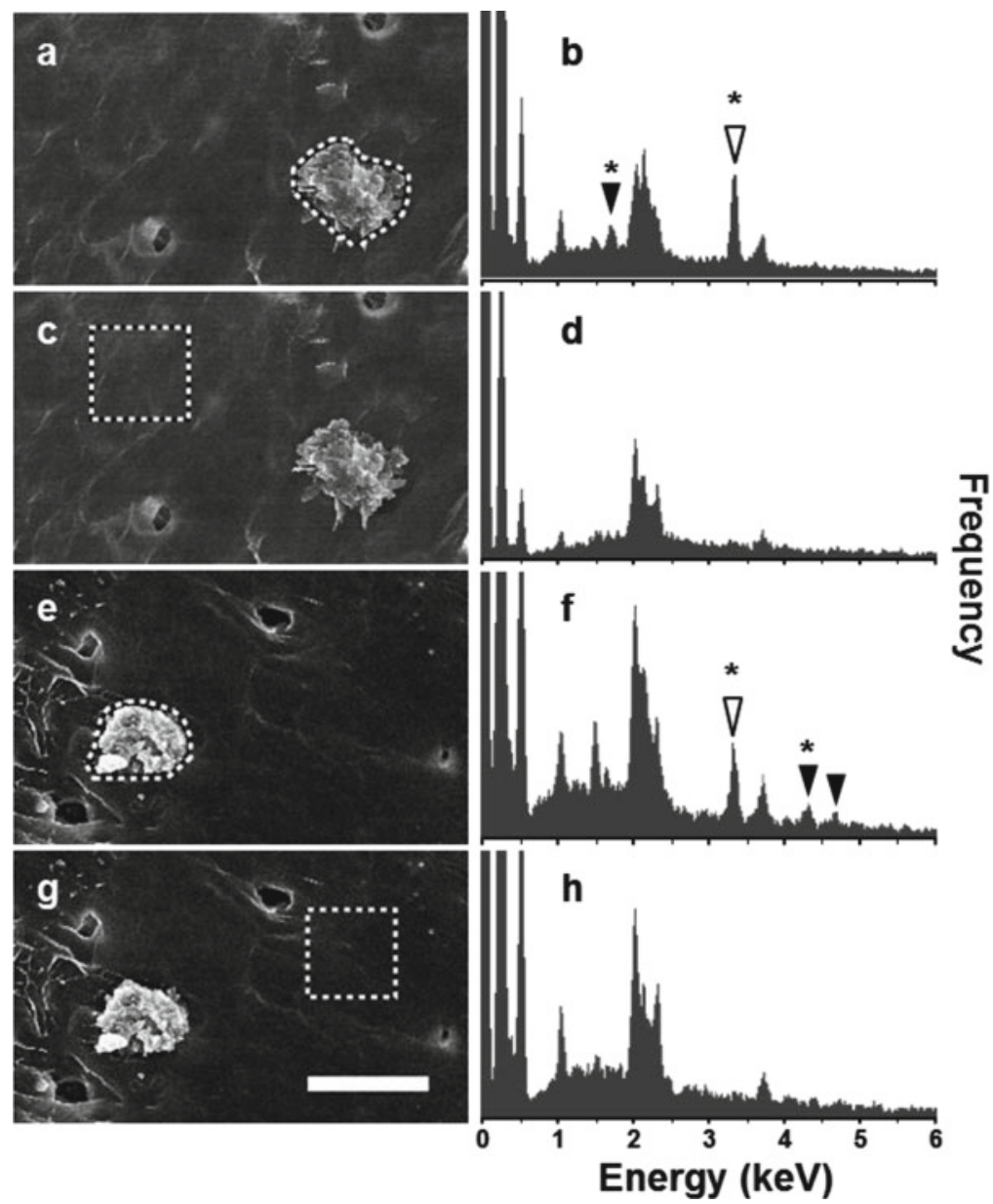

Fig. 11.6 Scanning electron micrographs $(\mathbf{a}, \mathbf{c}, \mathbf{e}, \mathbf{g})$ and energy dispersive X-ray spectrometry (EDS) profiles $(\mathbf{b}, \mathbf{d}, \mathbf{f}, \mathbf{h})$ of gills infused with $\mathrm{Rb}^{+}(\mathbf{a}-\mathbf{d})$ and $\mathrm{Cs}^{+}(\mathbf{e}-\mathbf{h})$. The amorphous and square lines $(\mathbf{a}, \mathbf{c}, \mathbf{e}, \mathbf{g})$ indicate the areas subjected to EDS analysis $(\mathbf{b}, \mathbf{d}, \mathbf{f}, \mathbf{h})$. White arrowheads indicate a representative $\mathrm{X}$-ray energy peak of $\mathrm{K}$. The black arrowhead in panel $\mathbf{b}$ indicates an energy peak of $\mathrm{Rb}$, whereas the black arrowheads in panel $\mathbf{f}$ indicate those of Cs. Bar, $10 \mu \mathrm{m}$ (from Furukawa et al. 2012b)

\subsection{Perspectives}

Our findings clearly elucidated the branchial $\mathrm{Cs}^{+}$and $\mathrm{Rb}^{+}$eliminating pathways through the ROMK-based $\mathrm{K}^{+}$excretion mechanism of MR cells in seawateracclimated Mozambique tilapia (Fig. 11.8). The radioactive Cs fallout generated by the recent nuclear disaster at the Fukushima Daiichi nuclear power plant in Japan is an extremely serious environmental issue that needs to be addressed urgently. The present study provides important information about the possible elimination 


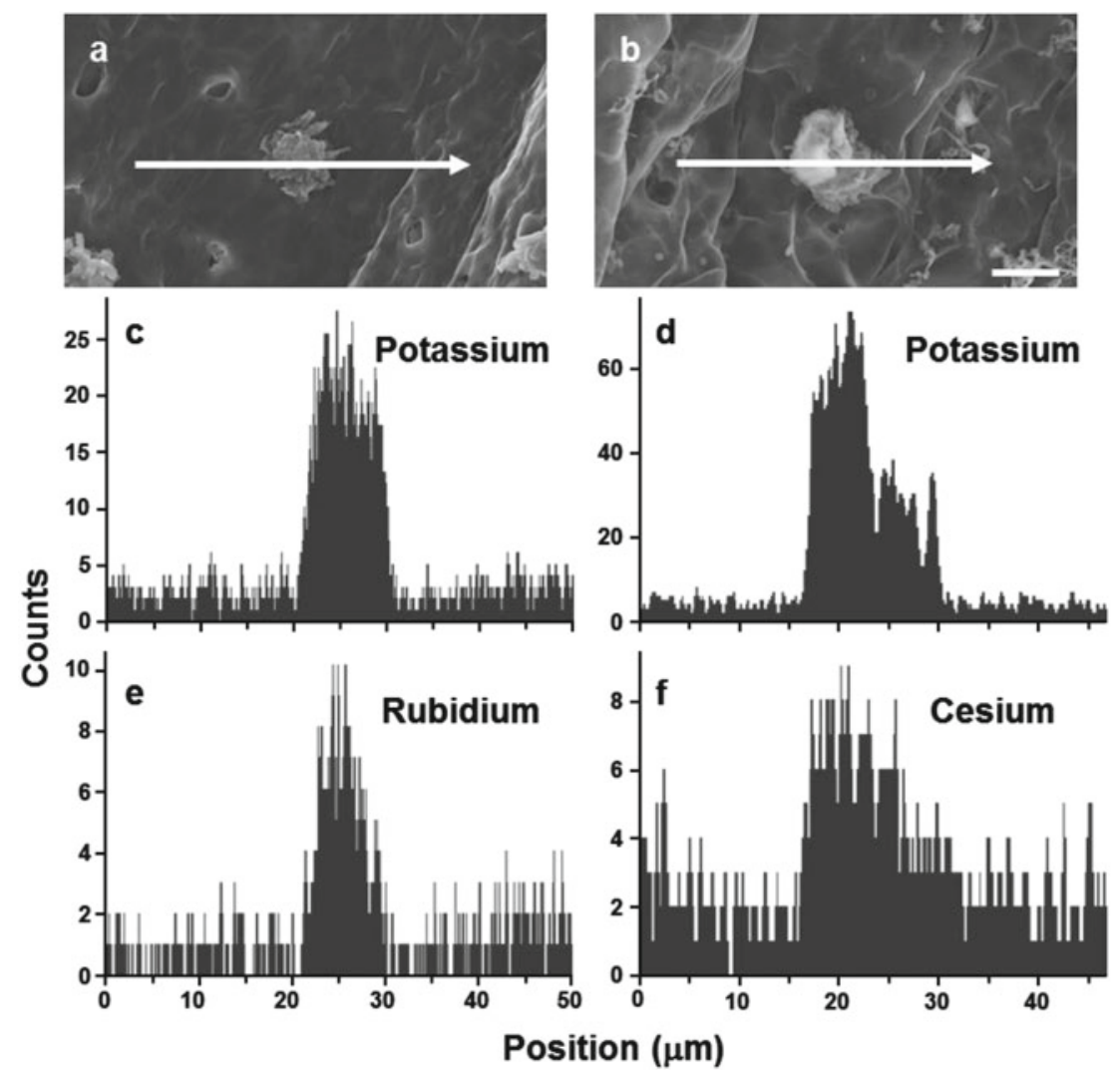

Fig. 11.7 Line-scanning element analyses of gills infused with $\mathrm{Rb}^{+}(\mathbf{a}, \mathbf{c}, \mathbf{e})$ and $\mathrm{Cs}^{+}(\mathbf{b}, \mathbf{d}, \mathbf{f})$. Analyses were performed on the arrows crossing the precipitates in panels (a) and (b) at $3.31 \mathrm{keV}$ for $\mathrm{K}(\mathbf{c}, \mathbf{d}), 1.69 \mathrm{keV}$ for Rb (e), and $4.29 \mathrm{keV}$ for Cs (f). Bar, $10 \mu \mathrm{m}$ (from Furukawa et al. 2012b)

route of Cs in marine teleosts, which clearly enhances our understanding of the metabolism of radiocesium in teleosts. The excretion of biochemical analogs of $\mathrm{K}^{+}$ probably accounts for the shorter biological half-life of ${ }^{137} \mathrm{Cs}$ in marine teleosts than freshwater teleosts (Kasamatsu 1999). In euryhaline Mozambique tilapia, ROMK is expressed in the gills in seawater and freshwater, although its expression level is lower in freshwater than in seawater (Furukawa et al. 2012a), suggesting that freshwater teleosts may also possess the ability to excrete $\mathrm{Cs}^{+}$through their $\mathrm{MR}$ cells. The activation of ROMK in MR cells induced by $\mathrm{K}^{+}$supplementation could eliminate unnecessary biochemical analogs of $\mathrm{K}^{+}$more rapidly, possibly acting as an effective countermeasure for radiocesium in aquaculture.

Open Access This article is distributed under the terms of the Creative Commons Attribution Noncommercial License which permits any noncommercial use, distribution, and reproduction in any medium, provided the original author(s) and source are credited. 


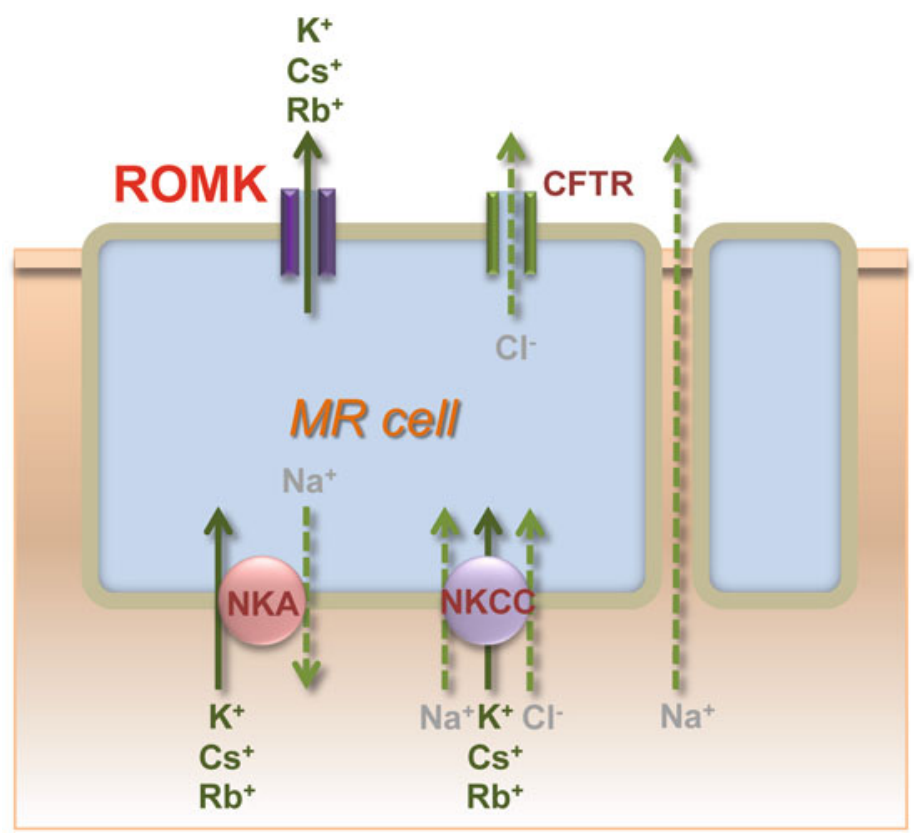

Fig. 11.8 Molecular mechanisms of $\mathrm{K}^{+}, \mathrm{Cs}^{+}$, and $\mathrm{Rb}^{+}$secretion from mitochondria-rich (MR) cells in seawater fish, involving the cooperative actions of three major ion transporters: $\mathrm{Na}^{+} / \mathrm{K}^{+}$ ATPase (NKA), $\mathrm{Na}^{+} / \mathrm{K}^{+} / 2 \mathrm{Cl}^{-}$cotransporter (NKCC), and renal outer medullary $\mathrm{K}^{+}$channel (ROMK)

\section{References}

Evans DH, Piermarini PM, Choe KP (2005) The multifunctional fish gill: dominant site of gas exchange, osmoregulation, acid base regulation, and excretion of nitrogenous waste. Physiol Rev 85:97-177

Furukawa F, Watanabe S, Kimura S, Kaneko T (2012a) Potassium excretion through ROMK potassium channel expressed in gill mitochondrion-rich cells of Mozambique tilapia. Am J Physiol Regul Integr Comp Physiol 302:R568-R576

Furukawa F, Watanabe S, Kaneko T (2012b) Excretion of cesium and rubidium via the branchial potassium-transporting pathway in Mozambique tilapia. Fish Sci 78:597-602

Hebert SC, Desir G, Giebisch G, Wang W (2005) Molecular diversity and regulation of renal potassium channels. Physiol Rev 85:319-371

Hirose S, Kaneko T, Naito N, Takei Y (2003) Molecular biology of major components of chloride cells. Comp Biochem Physiol B 136:593-620

Hwang PP, Lee TH, Lin LY (2011) Ion regulation in fish gills: recent progress in the cellular and molecular mechanisms. Am J Physiol Regul Integr Comp Physiol 301:R28-R47

Inokuchi M, Hiroi J, Watanabe S, Lee KM, Kaneko T (2008) Gene expression and morphological localization of NHE3, NCC and NKCC1 in branchial mitochondrion-rich cells. Comp Biochem Physiol A 151:151-158

Kaneko T, Watanabe S, Lee KM (2008) Functional morphology of mitochondria-rich cells in euryhaline and stenohaline teleosts. Aqua BioSci Monogr 1:1-62 
Kasamatsu F (1999) Marine organisms and radionuclides - with special reference to the factors affecting concentration of ${ }^{137} \mathrm{Cs}$ in marine fish. Radioisotopes 48:266-282 (in Japanese)

Marshall WS, Grosell M (2006) Ion transport, osmoregulation, and acid-base balance. In: Evans DH, Claiborne JB (eds) The physiology of fishes, 3rd edn. CRC, Boca Raton, pp 177-230

McCormick SD (1995) Hormonal control of gill $\mathrm{Na}^{+}, \mathrm{K}^{+}$-ATPase and chloride cell function. In: Wood CM, Shuttleworth TJ (eds) Fish Physiology, vol XIV, Cellular and molecular approaches to fish ionic regulation. Academic, New York, pp 285-315

Peters EI, Shultz IR, Newman MC (1999) Rubidium and cesium kinetics and tissue distributions in channel catfish (Ictalurus punctatus). Ecotoxicology 8:287-300

Relman AS (1956) The physiological behavior of rubidium and cesium in relation to that of potassium. Yale J Biol Med 29:248-262

Their SO (1986) Potassium physiology. Am J Med 80:3-7

Wang WH, Giebisch G (2009) Regulation of potassium (K) handling in the renal collecting duct. Eur J Physiol 458:157-168 